\title{
Hyperammonaemia in 20 families \\ Biochemical and genetical survey, including investigations in 3 new families
}

\author{
T. PALMER, V. G. OBERHOLZER, E. ANN BURGESS, L. J. BUTLER, and B. LEVIN* \\ From the Biochemistry Department, Queen Elizabeth Hospital for Children, London
}

\begin{abstract}
Palmer, T., Oberholzer, V. G., Burgess, E. A., Butler, L. J., and Levin, B. (1974). Archives of Disease in Childhood, 49, 443. Hyperammonaemia in 20 families: biochemical and genetical survey, including investigations in 3 new families. Investigations have been made in 3 new and 2 previously reported families with ornithine transcarbamylase defects and the results are reported. The biochemical findings relevant to the diagnosis of hyperammonaemia in these and the 15 other families known to be affected are tabulated. In 2 families where the propositus appears to have a variant type of ornithine transcarbamylase defect, the mode of inheritance is uncertain. In the other 18 families, while it cannot be assumed that all affected cases are suffering from the results of an identical mutation, there is good evidence for an X-linked dominant mode of inheritance, and no positive evidence in any family for a different mode of inheritance.
\end{abstract}

Hyperammonaemia due to a deficiency of hepatic ornithine transcarbamylase (OTC) activity was first described by Russell et al. (1962) and the clinical and biochemical features in several patients have been reviewed (Levin, 1971; Shih and Efron, 1972). Together with other urea cycle defects, it may be indicated by mental and physical retardation coupled with protein intolerance, raised plasma levels of ammonia, glutamine, and sometimes alanine, and increased urinary excretion of ammonia and pyrimidine metabolites (Levin, 1971; Palmer, 1973). Though distinguishable from the other diseases of the urea cycle by the failure to find raised quantities of citrulline, argininosuccinic acid, or arginine in the plasma or urine, hyperammonaemia can only be diagnosed with certainty by assay of the liver enzymes of the urea cycle.

In addition to the 13 families included in the recent review of Short et al. (1973), 7 further families are now known to be affected (referencessee Table I). Investigations into 3 of these are described here, together with further studies on 2 previously documented ones. The mode of inheritance is discussed in the light of the new results.

\footnotetext{
Received 13 November 1973.
}

^Present address : East Ham Memorial Hospital, London E7 8QR.
The form of hyperammonaemia caused solely by a carbamyl phosphate synthetase (CPS) deficiency (Freeman et al., 1970; Odièvre et al., 1973) is a separate topic and will not be considered here.

\section{Methods}

The methods used for the detection of hyperammonaemia have been previously described (Levin $e t$ al., 1969a, b, c). Blood for amino acid determinations was collected in each case before and after a protein load ingested during the morning (Palmer et al., 1973). Protein was given as a stress to the urea cycle.

\section{Summary of present results and previously reported findings}

The biochemical findings relevant to the diagnosis of hyperammonaemia in all members of families known to be affected are summarized in Table I.

Plasma levels of ammonia above the upper limit of normal, including high levels found only after a protein load, are indicated by + , normal ammonia levels and/or a normal response by - . Raised and normal plasma glutamine levels are similarly indicated, though this important amino acid was not estimated in the majority of the subjects. In those cases where the plasma glutamine had decayed before it could be estimated, the probability of a raised or normal initial glutamine level was deduced 
Summary of relevant findings in families with 1 or more members havin

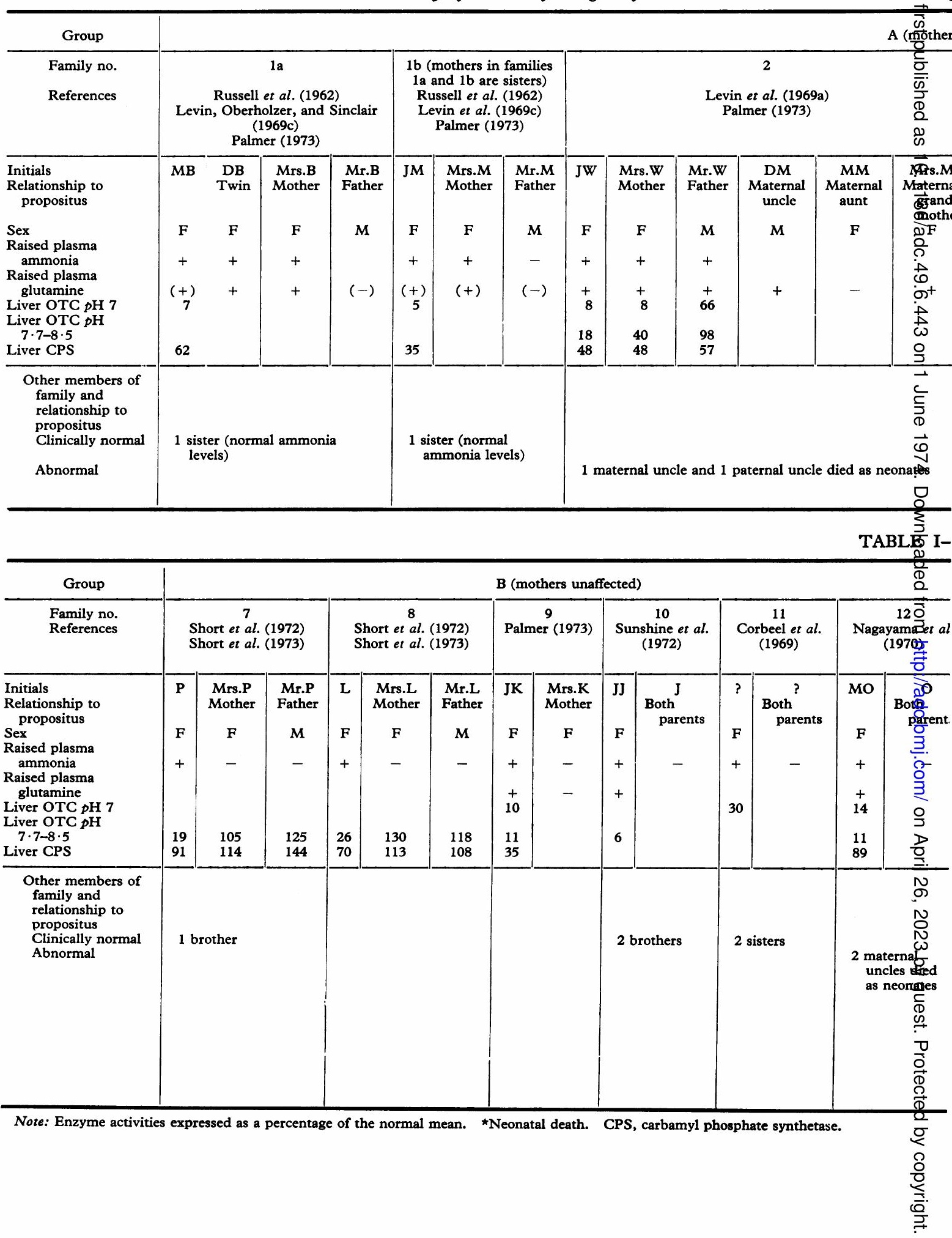


deficiency of liver ornithine transcarbamylase activity (OTC)

\begin{tabular}{|c|c|c|c|c|c|c|c|c|c|c|c|c|c|c|}
\hline \multicolumn{4}{|c|}{$\begin{array}{l}\text { Campbell et al. (1971) } \\
\text { Campbell et al. (1973) } \\
\text { Short et al. (1973) }\end{array}$} & \multicolumn{5}{|c|}{$\begin{array}{l}\text { Short et al. (1972) } \\
\text { Short et al. (1973) }\end{array}$} & \multicolumn{3}{|c|}{$\begin{array}{l}5 \\
\text { Cathelineau et al. (1972) }\end{array}$} & \multicolumn{3}{|c|}{$\begin{array}{l}6 \\
\text { le et al. (1972) } \\
\text { Imer }(1973)\end{array}$} \\
\hline$M^{\star}$ & $\begin{array}{c}\mathbf{M}^{\star} \\
\text { Brother }\end{array}$ & $\begin{array}{l}\text { Mrs.M } \\
\text { Mother }\end{array}$ & $\begin{array}{l}\text { Mr.M } \\
\text { Father }\end{array}$ & C & $\begin{array}{c}\mathrm{C}^{\star} \\
\text { Brother }\end{array}$ & $\begin{array}{l}\text { Mrs.C } \\
\text { Mother }\end{array}$ & $\begin{array}{l}\text { Mr.C } \\
\text { Father }\end{array}$ & $\begin{array}{l}? \\
\text { Maternal } \\
\text { aunt }\end{array}$ & VL & $\begin{array}{l}\text { Mrs.L } \\
\text { Mother }\end{array}$ & $\begin{array}{l}\text { Mr.L } \\
\text { Father }\end{array}$ & EM & $\begin{array}{l}\text { Mrs.M } \\
\text { Mother }\end{array}$ & $\begin{array}{l}\text { Mr.M } \\
\text { Father }\end{array}$ \\
\hline $\mathbf{M}$ & $\mathbf{M}$ & $\mathbf{F}$ & $M$ & $\mathbf{F}$ & $\mathbf{M}$ & $\mathbf{F}$ & $\mathbf{M}$ & $\mathbf{F}$ & $\mathbf{F}$ & $\mathbf{F}$ & $\mathbf{M}$ & $F$ & $\mathbf{F}$ & $\mathbf{M}$ \\
\hline+ & $\begin{array}{l}+ \\
+\end{array}$ & + & - & + & + & + & - & + & + & $\begin{array}{l}+ \\
12\end{array}$ & - & $\begin{array}{l}+ \\
+ \\
10\end{array}$ & + & + \\
\hline $210^{0.4}$ & $110^{0 \cdot 1}$ & $\begin{array}{l}98 \\
81\end{array}$ & $\begin{array}{r}103 \\
91\end{array}$ & 23 & $\begin{array}{l}11,0 \\
147\end{array}$ & $\begin{array}{r}39 \\
102\end{array}$ & $\begin{array}{r}99 \\
152\end{array}$ & 63 & $\begin{array}{l}12 \\
73\end{array}$ & $\begin{array}{l}43 \\
59\end{array}$ & & $\begin{array}{l}36 \\
10\end{array}$ & & \\
\hline $\begin{array}{l}1 \text { bro } \\
\text { still }\end{array}$ & $\begin{array}{l}\text { ther died as } \\
\text { lborn }\end{array}$ & neonate; & nother & $\begin{array}{l}3 \mathrm{br} \\
1 \mathrm{br} \\
\mathrm{ne}\end{array}$ & $\begin{array}{l}\text { hers, } 1 \text { sist } \\
\text { her and } 3 \text {, } \\
\text { hates }\end{array}$ & naternal u & cles died & & 1 bro & $\begin{array}{l}\text { her, } 1 \text { sist } \\
r \text { died at }\end{array}$ & & $\begin{array}{l}1 \mathrm{sis} \\
1 \mathrm{br} \\
\text { ne }\end{array}$ & her died as & \\
\hline
\end{tabular}

continued

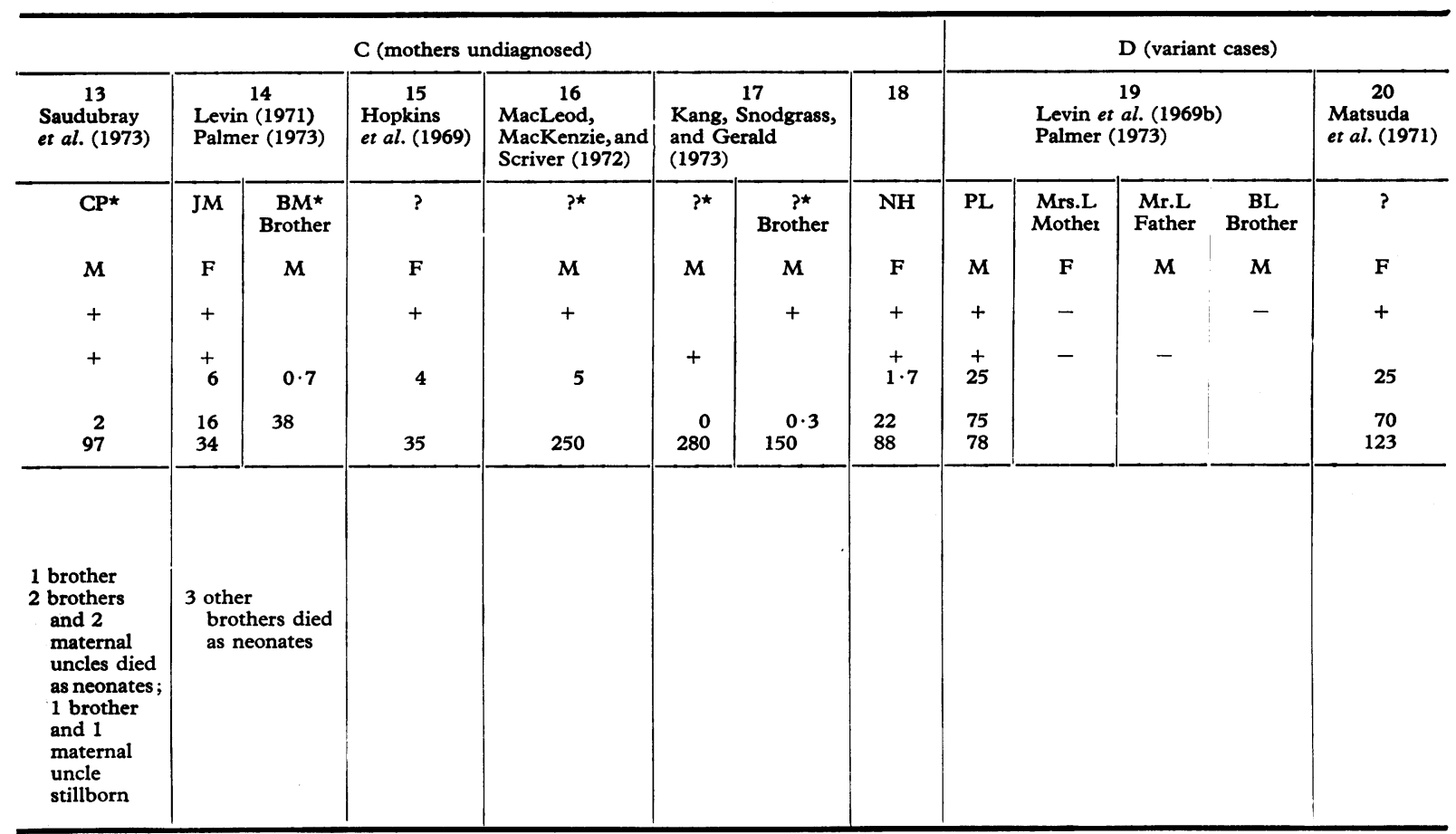


from the observed glutamic acid level (Palmer, 1973) and indicated in Table $I$ by (+) and (-), respectively. Also included are the liver OTC activities at $p \mathrm{H} 7$ and $7 \cdot 7-8 \cdot 5$ and liver CPS activities. OTC activities measured between $p \mathrm{H}$ $7 \cdot 7$ and 8.5 have been grouped together, though results do vary with the different buffers which have been used by various investigators. For better comparison, the activities have been expressed in Table I as a percentage of the mean activity obtained in controls by the same investigators under the same conditions. In the controls investigated by us, the lowest OTC activity was $76 \%$ of the mean at $p \mathrm{H} \mathrm{7}$, and $67 \%$ of the mean at $p \mathrm{H} 8$. The lowest CPS activity was $57 \%$ of the mean.

Most of the information in Table I has been compiled from data published in detail. Relevant references are given. However, there are 5 families in which some or all of the investigations have not previously been published, and results of these are reported here.

\section{Present investigations.}

Family 2 (Table I). This is the family in which hyperammonaemia in mother and child was first reported (Levin et al., 1969a). Amino acid levels in plasma and urine from 3 members of the family have now been determined. Both the maternal grandmother and maternal uncle of the propositus had high plasma and urine glutamine levels, but those of a maternal aunt were normal (Table IV; Palmer, 1973). The father of the propositus was examined on two occasions and on each he had slightly raised fasting plasma glutamine levels, 14.0 and 13.8 $\mathrm{mg} / 100 \mathrm{ml}$. Corresponding plasma ammonia levels were also raised, 63 and $67 \mu \mathrm{g} \mathrm{NH}_{3}-\mathrm{N} / 100 \mathrm{ml}$.

Family 9 (Table I). The propositus, J.K., was a 4-year-old Yugoslav girl who also had unexplained ketosis. A biopsy specimen of her liver had a low
OTC activity (Table II). Amino acid levels in plasma collected fasting and 3 hours after a protein load from the patient and her mother are given in Tables III and IV, respectively. Raised plasma glutamine levels were found in both specimens from the child, while those from the mother were normal. All other plasma amino acid levels were within normal limits for both subjects. The corresponding plasma ammonia levels of the affected girl were also high, 185 and $400 \mu \mathrm{g} \mathrm{NH}-\mathrm{N} / 100 \mathrm{ml}$ respectively, whereas the fasting level of the mother was normal, $39 \mu \mathrm{g} \mathrm{NH}_{3}-\mathrm{N} / 100 \mathrm{ml}$.

Family 14 (Table I). The propositus, J.M., was a 2-year-old West German girl. The OTC activity in a biopsy liver specimen was low (Table II). Plasma, urine, and CSF amino acid levels have been given in an earlier review (Levin, 1971, Table 6). 4 of her brothers died as neonates, and the liver OTC activity in a necropsy specimen from one, B.M., was found to be low (Table II).

Family 18 (Table I). The propositus, N.H., a girl, died at the age of 5 years, a few months after the onset of symptoms. Hyperammonaemia was diagnosed at the Willink Biochemical Genetics Laboratory, Royal Manchester Children's Hospital, and an OTC defect was shown in a necropsy liver specimen at our laboratory (Table II).

Family 19 (Table I). Levels of all plasma amino acids, including glutamine, of the father and younger brother of a boy, P.L., described as having a variant type of OTC defect (Levin et al., 1969b), were normal (Palmer, 1973). Plasma ammonia was determined in the brother of the propositus and was also found to be normal. The plasma glutamine level of P.L. has been consistently high in spite of treatment by low protein intake, and when last measured at the age of 5 years it was $18.5 \mathrm{mg} / 100$ $\mathrm{ml}$.

TABLE II

Hepatic urea cycle enzyme activities ( $\mu$ mol/hr per $g$ wet weight)

\begin{tabular}{|c|c|c|c|c|c|c|}
\hline & \multicolumn{2}{|c|}{ OTC } & \multirow{2}{*}{ CPS } & \multirow{2}{*}{ ASS } & \multirow{2}{*}{ ASL } & \multirow{2}{*}{ A } \\
\hline & $p H \mathbf{H} \cdot 0$ & $p \mathrm{H} 8 \cdot 0$ & & & & \\
\hline $\begin{array}{l}\text { JK (family 9) } \\
\text { JM (family 14) } \\
\text { BM (family 14) } \\
\text { NH (family 18) } \\
\text { Controls } \\
\text { Lowest } \\
\text { Highest }\end{array}$ & $\begin{array}{r}528 \\
308 \\
36 \\
171 \\
3950 \\
6650\end{array}$ & $\begin{array}{r}622 \\
950 \\
2200 \\
1315 \\
3900 \\
9090\end{array}$ & $\begin{array}{l}111 \\
108 \\
280 \\
182 \\
615\end{array}$ & $\begin{array}{r}12 \\
9 \\
9 \\
29 \\
21 \\
41\end{array}$ & $\begin{array}{r}176 \\
14 \\
109 \\
100 \\
177\end{array}$ & $\begin{array}{l}24,500 \\
26,400 \\
25,600 \\
15,100 \\
\\
24,600 \\
56,300\end{array}$ \\
\hline
\end{tabular}

OTC, ornithine transcarbamylase; CPS, carbamyl phosphate synthetase; ASS, argininosuccinate synthetase; ASL, argininosuccinate lyase; A, arginase. 
TABLE III

Plasma levels ( $\mathrm{mg} / 100 \mathrm{ml}$ ) of some amino acids before and after protein meals (1 $\mathrm{g}$ protein $/ \mathrm{kg}$ body weight) in a girl with hyperammonaemia and in controls

\begin{tabular}{|c|c|c|c|c|c|c|}
\hline & \multicolumn{2}{|c|}{$\begin{array}{c}\text { JK (4 yr) } \\
\text { (Table I, family 9) }\end{array}$} & \multicolumn{4}{|c|}{$\begin{array}{c}6 \text { controls (4 mth-4 yr) } \\
\text { (Palmer, 1973) }\end{array}$} \\
\hline & \multirow{2}{*}{ Fasting } & \multirow{2}{*}{$3 \mathrm{hr}$} & \multicolumn{2}{|c|}{ Fasting } & \multicolumn{2}{|c|}{$2 \mathrm{hr}$} \\
\hline & & & Mean & SD & Mean & SD \\
\hline $\begin{array}{l}\text { Glutamine } \\
\text { Glutamic acid } \\
\text { Citrulline } \\
\text { Glycine } \\
\text { Alanine } \\
\text { Leucine } \\
\text { Ornithine } \\
\text { Lysine } \\
\text { Arginine }\end{array}$ & $\begin{array}{c}24 \cdot 4 \\
0 \cdot 51 \\
0 \cdot 12 \\
1 \cdot 05 \\
1 \cdot 55 \\
0 \cdot 80 \\
0 \cdot 50 \\
1 \cdot 55 \\
0.53\end{array}$ & $\begin{array}{l}25 \cdot 6 \\
0 \cdot 80 \\
0 \cdot 22 \\
0 \cdot 98 \\
2 \cdot 2 \\
1 \cdot 7 \\
0 \cdot 73 \\
2 \cdot 4 \\
0 \cdot 47\end{array}$ & $\begin{array}{l}9 \cdot 0 \\
1 \cdot 0 \\
0 \cdot 38 \\
1 \cdot 35 \\
1 \cdot 70 \\
1 \cdot 35 \\
0 \cdot 56 \\
1 \cdot 85 \\
0 \cdot 96\end{array}$ & $\begin{array}{l}0.9 \\
0.35 \\
0 \cdot 15 \\
0.35 \\
0.25 \\
0 \cdot 25 \\
0.09 \\
0.30 \\
0 \cdot 10\end{array}$ & $\begin{array}{l}9 \cdot 8 \\
1 \cdot 30 \\
0 \cdot 45 \\
1 \cdot 10 \\
2 \cdot 15 \\
2 \cdot 60 \\
0 \cdot 90 \\
2 \cdot 95 \\
1 \cdot 20\end{array}$ & $\begin{array}{l}0.8 \\
0.60 \\
0.12 \\
0.20 \\
0.35 \\
0.50 \\
0.20 \\
0.15 \\
0.10\end{array}$ \\
\hline
\end{tabular}

TABLE IV

Plasma levels $(\mathrm{mg} / 100 \mathrm{ml})$ of some amino acids before and after protein meals $(0.65-0.85 \mathrm{~g}$ protein $/ \mathrm{kg}$ body weight) in adult members of affected families and in controls

\begin{tabular}{|c|c|c|c|c|c|c|c|c|c|c|c|c|}
\hline & \multicolumn{2}{|c|}{$\begin{array}{c}\text { Mrs. K } \\
\text { (Table I, family 9) }\end{array}$} & \multicolumn{2}{|c|}{$\begin{array}{c}\text { Mrs. M } \\
\text { (Table I, family 2) }\end{array}$} & \multicolumn{2}{|c|}{$\begin{array}{c}\text { MM } \\
\text { (Table I, family 2) }\end{array}$} & \multicolumn{2}{|c|}{$\begin{array}{c}\text { DM } \\
\text { (Table I, family 2) }\end{array}$} & \multicolumn{4}{|c|}{$\begin{array}{l}7 \text { adult controls } \\
\text { (Palmer, 1973) }\end{array}$} \\
\hline & \multirow{2}{*}{ Fasting } & \multirow{2}{*}{$3 \mathrm{hr}$} & \multirow{2}{*}{ Fasting } & \multirow{2}{*}{$3 \mathrm{hr}$} & \multirow{2}{*}{ Fasting } & \multirow{2}{*}{$3 \mathrm{hr}$} & \multirow{2}{*}{ Fasting } & \multirow{2}{*}{$3 \mathrm{hr}$} & \multicolumn{2}{|c|}{ Fasting } & \multicolumn{2}{|c|}{$2 \mathrm{hr}$} \\
\hline & & & & & & & & & Mean & SD & Mean & SD \\
\hline $\begin{array}{l}\text { Glutamine } \\
\text { Glutamic acid } \\
\text { Citrulline } \\
\text { Glycine } \\
\text { Alanine } \\
\text { Leucine } \\
\text { Ornithine } \\
\text { Lysine } \\
\text { Arginine }\end{array}$ & $\begin{array}{l}10 \cdot 0 \\
0 \cdot 71 \\
0 \cdot 07 \\
1 \cdot 9 \\
1 \cdot 95 \\
0 \cdot 96 \\
0.43 \\
1 \cdot 85 \\
0 \cdot 77\end{array}$ & $\begin{array}{l}11 \cdot 1 \\
1 \cdot 1 \\
0 \cdot 14 \\
2 \cdot 0 \\
2 \cdot 85 \\
3 \cdot 2 \\
0 \cdot 94 \\
4 \cdot 55 \\
2 \cdot 3\end{array}$ & $\begin{array}{l}15 \cdot 5 \\
0 \cdot 43 \\
0 \cdot 54 \\
1 \cdot 9 \\
3 \cdot 5 \\
1 \cdot 0 \\
0 \cdot 72 \\
2 \cdot 2 \\
1 \cdot 1\end{array}$ & $\begin{array}{l}17 \cdot 0 \\
0 \cdot 96 \\
0 \cdot 44 \\
2 \cdot 2 \\
3 \cdot 7 \\
1 \cdot 9 \\
1 \cdot 0 \\
2 \cdot 9 \\
1 \cdot 7\end{array}$ & $\begin{array}{l}9 \cdot 7 \\
0 \cdot 38 \\
0 \cdot 36 \\
1 \cdot 7 \\
2 \cdot 8 \\
0 \cdot 97 \\
0 \cdot 51 \\
2 \cdot 0 \\
1 \cdot 7\end{array}$ & $\begin{array}{l}12 \cdot 2 \\
1 \cdot 2 \\
0 \cdot 39 \\
2 \cdot 0 \\
3 \cdot 8 \\
2 \cdot 2 \\
0 \cdot 86 \\
3 \cdot 1 \\
2 \cdot 4\end{array}$ & $\begin{array}{l}15 \cdot 0 \\
0 \cdot 64 \\
0 \cdot 56 \\
2 \cdot 2 \\
3 \cdot 2 \\
1 \cdot 3 \\
0 \cdot 95 \\
2 \cdot 3 \\
1 \cdot 7\end{array}$ & $\begin{array}{l}17 \cdot 0 \\
1 \cdot 1 \\
0 \cdot 69 \\
2 \cdot 9 \\
4 \cdot 7 \\
2 \cdot 0 \\
1 \cdot 1 \\
3 \cdot 6 \\
2 \cdot 9\end{array}$ & $\begin{array}{l}9 \cdot 9 \\
0 \cdot 72 \\
0 \cdot 44 \\
1 \cdot 60 \\
2 \cdot 80 \\
1 \cdot 35 \\
0 \cdot 62 \\
2 \cdot 50 \\
1 \cdot 45\end{array}$ & $\begin{array}{l}1 \cdot 5 \\
0 \cdot 25 \\
0 \cdot 14 \\
0 \cdot 20 \\
0 \cdot 55 \\
0 \cdot 20 \\
0 \cdot 12 \\
0 \cdot 45 \\
0 \cdot 25\end{array}$ & $\begin{array}{l}12 \cdot 2 \\
0 \cdot 88 \\
0 \cdot 50 \\
2 \cdot 00 \\
3 \cdot 60 \\
3 \cdot 05 \\
1 \cdot 00 \\
5 \cdot 05 \\
2 \cdot 80\end{array}$ & $\begin{array}{l}1 \cdot 3 \\
0 \cdot 12 \\
0 \cdot 12 \\
0 \cdot 35 \\
0 \cdot 50 \\
0 \cdot 50 \\
0 \cdot 10 \\
0 \cdot 65 \\
0 \cdot 50\end{array}$ \\
\hline
\end{tabular}

Classification of families in Table I. In all affected members of families 1-18, the liver OTC activities at both $p \mathrm{H} 7$ and $7 \cdot 7-8 \cdot 5$, where measured, were found to be conspicuously low. However, it does not necessarily follow that they are all suffering from an identical genetic defect. On the basis of the diagnostic features discussed above, the fathers of affected cases, with possibly two exceptions to be discussed later, appear to be normal, while the mothers are clearly affected in some families but not in others. The 18 families have therefore been grouped into those where the mother is affected (group A), those where she appears to be unaffected (group B), and those where the situation is unknown (group C). Group A includes one instance (family 3 ) in which a biopsy liver specimen from the mother had a normal OTC activity. However, she had high plasma ammonia levels and was considered by the investigators (Short et al., 1973) to be affected.

The propositi in families 19 and 20 had conspicuously reduced liver OTC activities at $p \mathrm{H} \mathrm{7,} \mathrm{but}$ activities at $p \mathrm{H} 7 \cdot 7-8 \cdot 5$ were near the lower limit of normal. These 2 children were thus considered to have a variant form of OTC deficiency, and they have here been placed in a separate group (group D).

From Table I, it can be seen that liver CPS activities in affected females tended to be low, and this was very conspicuous in 1 case (family 6). In contrast, the CPS activities in affected males were never low, and, in fact, raised levels were seen in some cases. The significance of this is not known.

Raised fasting plasma glutamine levels were found in all the affected patients where this was accurately measured. Thus it seems that hyperammonaemia can always be indicated by an abnormal fasting 
glutamine level, without the necessity of performing protein loading tests.

\section{Inheritance of hyperammonaemia}

In the first family to be reported (Table I, families 1a and 1b) the 3 affected children were all girls. Their mothers, who were sisters, appeared to be similarly affected for they had raised plasma levels of glutamine and ammonia, and a reduced OTC activity was found in the jejunal mucosa of one of them. No abnormality was detected in the fathers. A dominant mode of inheritance was considered to fit these observations more closely than a recessive mode, for the latter would require that two sisters, both heterozygous for the disease gene, had married 2 unrelated heterozygous male carriers and that the heterozygous state was only detectable in females. Furthermore, apart from 1 male who had a variant form of the disease, the first 10 cases were all female. It was therefore concluded that the disease was not only dominant but possibly sex-limited also, and that the expression in males might be lethal (Levin et al., 1969a, c; Levin, 1971). In support of this suggestion a boy was later found to have an almost complete absence of liver OTC (Table I, family 3) and he died in the neonatal period. After a study of this and other families, Short et al. (1972, 1973) suggested that the disease might be X-linked, with affected males having a total defect of liver OTC and affected females only a partial defect with a mean activity of $25 \%$. The same conclusion was reached by Saudubray et al. (1973).

From the data now available (Table I), only the families in group A provide definite information concerning the mode of inheritance. In group B and the variant group $D$, where the parents were normal, the occurrence of sibships containing only a single affected individual makes it impossible to distinguish between a recessive mode and a fresh mutation, while in group $C$ the parents were not investigated.

Direct transmission from affected mothers to their offspring, shown in group A families, indicates a dominant mode of inheritance. For X-linkage to be present a number of factors must be satisfied. First, not only should both sexes be affected but the effects of random $\mathrm{X}$-inactivation by Lyonization (Lyon, 1962) should produce a more variable and therefore generally less severe disease in the heterozygous females than in the hemizygous males whose single $\mathrm{X}$ containing the mutant gene is always active. Secondly, equal groups of offspring, normal and abnormal, for each sex, should be produced by female carriers, assuming regular segregation of the $\mathrm{X}$ chromosomes. Thirdly, there should be no transmission of the disease from hemizygous fathers to their sons. However, males with hyperammonaemia appear to be so severely affected that they die in the neonatal period and never procreate, so that this consequence of $\mathrm{X}$-linked inheritance from affected fathers cannot be shown.

Obviously the number of individuals listed in group A of Table I who are the progeny of females known or assumed to be affected is too small for a detailed statistical analysis or for any sib corrections to be made for ascertainment bias. Nevertheless, if one assumes that all neonatal deaths among males in this group were due to the disease, then equal numbers of affected males and females, 11 of each, have occurred, and also nearly equal numbers of normal children of the two sexes, 4 males and 6 females. However, the numbers of normals and abnormals are not equal, for there are twice as many in the affected group compared with the normal group.

The main evidence for the hypothesis that inheritance is X-linked and dominant is the very different nature of the disease in the two sexes. Except in the variant group D, males are very severely affected, with enzyme activities close to zero. Females, on the other hand, have a range of enzyme activities from $4 \%$ of the normal mean up to normal values. This is consistent with random inactivation of the $\mathrm{X}$ chromosome (Lyonization).

The fathers of affected children appear to be normal, except in 2 families. In 1 (family 2), the father of the propositus had slightly raised plasma levels of glutamine and ammonia. His liver OTC activity at $p \mathrm{H} 8$ was normal, but at $p \mathrm{H} 7$ it was slightly low, and the enzyme was shown to have an abnormal $\mathrm{Km}$ to carbamyl phosphate. Thus, he may carry a gene for a variant type of hyperammonaemia, and the severity of his daughter's illness might have been due to the inheritance of a different type of hyperammonaemia from each parent. Also in family 2, the maternal uncle showed high glutamine levels in the only plasma specimens available, collected before and after a protein load, whereas similar specimens from the maternal aunt were found to be normal. In view of the limited studies made and the possibility of a labelling or other error before the arrival of the samples at our laboratory, these findings have to be treated with caution until they can be confirmed.

In the other family (family 6), the father may have had a slightly raised plasma glutamine level after a meal, but the result was equivocal since it was not known how much protein he had ingested. The propositus had very low hepatic activities of both OTC and CPS, so a variant disease with a recessive 
inheritance pattern might be involved in this case. However, the mother was clearly affected, with raised glutamine and alanine levels, and without more evidence this family cannot be considered different from the others in group A.

In conclusion, though it is impossible to satisfy all the criteria with the data available, there is strong evidence in many affected families for an X-linked dominant mode of inheritance for OTC deficiency, and while it cannot be assumed that all affected cases are suffering from an identical genetic defect, there is so far no positive evidence in any family for a different mode of inheritance.

We are grateful to Dr. J. Brodehl, University Kinderklinik, Bonn; to Dr. I. B. Sardharwalla, Royal Manchester Children's Hospital; to Professor D. Vulovic, Mother and Child Health Institute of Serbia; and to those consultants named in our previous communications, for allowing us to investigate their patients.

\section{REFERENCES}

Campbell, A. G. M., Rosenberg, L. E., Snodgrass, P. J., and Nuzum, C. T. (1971). Lethal neonatal hyperammonaemia due to complete ornithine-transcarbamylase deficiency. Lancet, 2 , 217.

Campbell, A. G. M., Rosenberg, L. E., Snodgrass, P. J., and Nuzum, C. T. (1973). Ornithine transcarbamylase deficiency: a cause of lethal neonatal hyperammonemia in males. New England Fournal of Medicine, 288, 1.

Cathelineau, L., Navarro, J., Aymard, P., Baudon, J-J., Mondet, Y., Polonovski, C., and Laplane, R. (1972). Hyperammoniémie héréditaire par anomalie qualitative de l'ornithine-carbamyltransférase hépatique et intestinale. Archives Francaises de Pédiatrie, 29, 713.

Corbeel, L. M., Colombo, J. P., van Sande, M., and Weber, A. (1969). Periodic attacks of lethargy in a baby with ammonia intoxication due to a congenital defect in ureogenesis. Archives of Disease in Childhood, 44, 681 .

Freeman, J. M., Nicholson, J. F., Schimke, R. T., Rowland, L. P., and Carter, S. (1970). Congenital hyperammonemia Association with hyperglycinemia and decreased levels of carbamyl phosphate synthetase. Archives of Neurology, 23, 430.

Hopkins, I. J., Connelly, J. F., Dawson, A. G., Hird, F. J. R., and Maddison, T. G. (1969). Hyperammonaemia due to ornithine transcarbamylase deficiency. Archives of Disease in Childhood, 44, 143.

Kang, E. S., Snodgrass, P. J., and Gerald, P. S. (1973). Ornithine transcarbamylase deficiency in the newborn infant. Fournal of Pediatrics, 82, 642.

Levin, B. (1971). Hereditary metabolic disorders of the urea cycle. Advances in Clinical Chemistry, 14, 65.

Levin, B., Abraham, J. M., Oberholzer, V. G., and Burgess, E. A. (1969a). Hyperammonaemia: a deficiency of liver ornithine transcarbamylase. Occurrence in mother and child. Archives of Disease in Childhood, 44, 152.

Levin, B., Dobbs, R. H., Burgess, E. A., and Palmer, T. (1969b) Hyperammonaemia: a variant type of deficiency of liver ornithine transcarbamylase. Archives of Disease in Childhood, 44, 162.

Levin, B., Oberholzer, V. G., and Sinclair, L. (1969c). Biochemical investigations of hyperammonaemia. Lancet, $2,170$.

Lyon, M. F. (1962). Sex chromatin and gene action in the mammalian X-chromosome. American fournal of Human Genetics, 14, 135

MacLeod, P., MacKenzie, S., and Scriver, C. R. (1972). Partial ornithine carbamyl transferase deficiency: an inborn error of the urea cycle presenting as orotic aciduria in a male infant. Canadian Medical Association fournal, 107, 405.

Matsuda, I., Arashima, S., Nambu, H., Takekoshi, Y., and Anakura, M. (1971). Hyperammonemia due to a mutant enzyme of ornithine transcarbamylase. Pediatrics, 48, 595.
Nagayama, E., Kitayama, T., Oguchi, H., Ogata, K., Tamura, E., and Onisawa, J. (1970). Hyperammonemia: a deficiency of liver ornithine transcarbamylase. Paediatria Universitatis Tokyo, 18, 167.

Odièvre, M., Charpentier, C., Cathelineau, L., Vedrenne, J., Delacoux des Roseaux, F., and Mercie, C. (1973). Hypérammoniémie constitutionnelle avec déficit en carbamylphosphate-synthétase. Archives Françaises de Pédiatrie, 30, 5.

Palmer, T. (1973). Amino acid levels in blood, urine and CSF of normal and sick children. Ph.D.Thesis. University of London.

Palmer, T., Rossiter, M. A., Levin, B., and Oberholzer, V. G. (1973). The effect of protein loads on plasma amino acid levels. Clinical Science and Molecular Medicine, 45, 827.

Russell, A., Levin, B., Oberholzer, V. G., and Sinclair, L. (1962). Hyperammonaemia: a new instance of an inborn enzymatic defect of the biosynthesis of urea. Lancet, 2, 699.

Salle, B., Levin, B., Longin, B., Richard, P., Andre, M., and Gauthier, J. (1972). Hyperammoniémie congénitale par déficit en ornithine-carbamyl-transférase et carbamyl-phosphatesynthétase. Archives Francaises de Pédiatrie, 29, 493.

Saudubray, J-M., Cathelineau, L., Charpentier, C., Boisse, J., Allaneau, C., Le Bont, H., and Lesage, B. (1973). Déficit héréditaire en ornithine-carbamyl-transférase avec anomalie enzymatique qualitative. Archives Francaises de Pédiatrie, 30, 15.

Shih, V. E., and Efron, M. L. (1972). Urea cycle disorders. In The Metabolic Basis of Inherited Disease, 3rd ed., p. $370 . \quad$ Ed. by J. B. Stanbury, J. B. Wyngaarden, and D. S. Fredrickson. McGraw-Hill, New York.

Short, E. M., Conn, H. O., Snodgrass, P. J., Campbell, A. G. M., and Rosenberg, L. E. (1973). Evidence for X-linked dominant inheritance of ornithine transcarbamylase deficiency. New England Fournal of Medicine, 288, 7.

Short, E. M., Conn, H. O., Snodgrass, P. J., and Rosenberg, L. E. (1972). Evidence for X-linked inheritance of ornithine transcarbamylase deficiency. Fournal of Clinical Investigation, 51, No. 6, 90a.

Sunshine, P., Lindenbaum, J. E., Levy, H. L., and Freeman, J. M. (1972). Hyperammonemia due to a defect in hepatic ornithine transcarbamylase. Pediatrics, 50, 100.

Correspondence to Dr. T. Palmer, Biochemistry Department, Queen Elizabeth Hospital for Children, Hackney Road, London E2 8PS.

\section{Addendum}

Three more cases of OTC deficiency have come to our notice. The first is a 3-year-old girl (Dr. M. M. Liberman, Northwick Park Hospital, Harrow) who has $22 \%$ of the normal hepatic OTC activity in $\mathrm{pH} 7$ buffer and $33 \%$ in $p \mathrm{H} 8$ buffer. Her 3 brothers, 2 sisters, and both parents had normal fasting plasma glutamine levels. The second is a boy (Professor J.-P. Farriaux, Lille, France) who has only $0.8 \%$ of the normal liver OTC activity in $p \mathrm{H} 7$ buffer, but has $30 \%$ of the normal activity in $p \mathrm{H} 8$ buffer. OTC activity has been assayed in intestinal biopsies from the parents. The mother's activity was $50 \%$ of normal while the father's intestine showed a normal activity. There are no sibs. The third case, described by Krebs, Hems, and Lund (1973), was a 13-month-old girl with a liver OTC activity $2 \%$ of normal. 2 brothers had died as infants and a sister died at 9 months of age. Another sister was normal. These cases do not change our conclusions as to the mode of inheritance of hyperammonaemia.

\section{REFERENCE}

Krebs, H. A., Hems, R., and Lund, P. (1973). Regulatory mechanisms in the synthesis of urea. In Inborn Errors of Metabolism, p. 201. Ed. by F. A. Hommes and C. J. Van Den Berg. Academic Press, London and New York. 